\title{
The Hope of Something Different: Eco-centricity in Art and Education
}

\author{
Chris Fremantle \\ Robert Gordon University, Gray's School of Art, United Kingdom \\ c.fremantle@rgu.ac.uk
}

\begin{abstract}
Educational theorist Gert Biesta proposes that we need to be "in the world without occupying the centre of the world." (Biesta, 2017, p. 3). This injunction provides a frame with which to interrogate the hybrid practice of ecoart. This practice can be characterised by a concern for the relations of living things to each other, and to their environments. Learning in order to be able to act is critical. One aspect is collaboration with experts (whether those are scientists and environmental managers or inhabitants, including more-than-human). Another is building 'commons' and shared understanding being more important than novelty. Grant Kester has argued that there is an underlying paradigm shift in 'aesthetic autonomy', underpinned by a 'trans-disciplinary interest in collective knowledge production'. (2013, np). This goes beyond questions of interdisciplinarity and its variations to raise more fundamental questions of agency.

Drawing on the work of key practitioner/researchers (eg Jackie Brookner (I945-20 I5); Collins and Goto Studio, Helen Mayer Harrison (1927-2018) and Newton Harrison (b 1932)) and theorists (Kester, Kagan) the meaning and implications of not 'occupying the centre of the world' will be explored as a motif for an art which can act in public space.
\end{abstract}

Keywords: ecoart, eco-centric, social practice, Gert Biesta, understanding

To cite this article:

Fremantle, C. (2020) The Hope of Something Different: Eco-centricity in Art and Education, The Journal of Public Space, 5(4), 67-86, DOI 10.3289I/jps.v5i4.I385

This article has been double blind peer reviewed and accepted for publication in The Journal of Public Space. (C) This work is licensed under a Creative Commons Attribution - Non Commercial 4.0 International License https://creativecommons.org/licenses/by-nc/4.0/ 


\title{
Introduction
}

Rather than rehearsing the conventional geological or activist definitions of the Anthropocene, this paper will use Helen Mayer Harrison and Newton Harrison, known as 'the Harrisons', framing of the environmental crises as 'the Force Majeure' to underpin our discussion of art and public space.' The Harrisons use this legal term for an extraordinary event or circumstance beyond control not for its connotation of loosening responsibility, but because it captures the conceptual shift required to understand that circumstances are beyond human control and we must now adapt. Their text 'A Manifesto for the Twenty-First Century', the founding document of The Center for the Study of the Force Majeure, articulates the Force Majeure in the following terms:

\author{
We at the Center assert \\ That the Force Majeure, framed ecologically \\ Enacts, in physical terms, outcomes on the ground \\ All that we have created in the global landscape \\ Bringing together the conditions that have accelerated global warming \\ Acting in concert with the massive industrial processes \\ of extraction, production, and consumption \\ That have subtracted forests, and depleted topsoil \\ And profoundly reduced ocean productivity \\ While creating a vast chemical outpouring into the atmosphere \\ Onto the lands and within the waters \\ That altogether comprise this Force Majeure \\ Initiating what might become the sixth mass extinction \\ We of the Center are grateful for the opportunity \\ To join in this perilous conversation \\ Where the discourse in general \\ Concerns time, money, power, justice, sex, politics \\ Personal well-being and survival \\ In many combinations and recombinations \\ Attending somewhat to social injustice \\ And much, much less to ecological injustice
}

(Harrison and Harrison, 2016, p. 378)

The Harrisons' say that we have reached the point where "everything we have created in the global landscape" is now the 'form determinant' of life. ${ }^{2}$ The question is how to adapt? Gert Biesta, educational theorist, argues that we need to understand how to be, "...in the world without occupying the centre of the world." (Biesta, 2017, p. 3).

After providing some context on ecoart, ${ }^{3}$ we'll explore its overlaps with social and place-based practices as well as its hybrid characteristics, before turning to the question of eco-centricity. ecoart is closely related to social practice, and some practitioners frame their work in terms of eco-social practices, including Cathy Fitzgerald who l'll

\footnotetext{
' Some of the ideas in this paper were previously published on A Restless Art (Fremantle 20I5)

2 The 'form determinant' is the combination of heatwave, sea level rise and biodiversity loss.

${ }^{3}$ ecoart is a neologism. It tends not to be capitalised to emphasise the ideas and work rather than the name.
} 
return to later. However understanding the distinctiveness of ecoart, in Bateson's terms 'the difference that makes a difference' (Bateson, 1979, p. 68-9), is important for activist practices as well as for public space. I will take up Biesta's conceptualisation and explore how that reveals aspects of practices which can address 'the Force Majeure'.

The question of usefulness, as a particular complexity in art and public space, will also recur throughout the discussion. Art is often asked to deliver engagement, address ecology, work with other disciplines, generate activism, develop relationality, but all of these can be achieved through other processes too. ${ }^{4}$ Usefulness is questioned as a characteristic of art because it can easily 'overwrite' the value of art - the use value 'trumping' the art value. Claire Bishop (Bishop, 20I2) makes this argument, as does Biesta. Usefulness, if left as a simplistic concept, stubbornly hinders understanding both social and ecoart and their value.

\section{Hybrid practices of art and ecology}

The Harrisons are pioneers of ecoart. They along with a number of other artists (e.g. Barucello, Beuys, Denes, Gilardi, Haacke, Johansson, Sonfist, Ukeles, and others) who have responded to the wave of environmental concern in the late $60 \mathrm{~s}$ and early 70 s by seeking to formulate a different basis for practice. ${ }^{5}$ Ecoart practices are often characterised in terms of the multiple environmental/ecological crises most of which affect and manifest public space. This includes global heating; waste and pollution in the many forms it is generated by extraction, production and consumption; biodiversity including the increasing rate of extinctions; as well as the impacts of monocultural approaches to forestry and agriculture particularly on soil but also on health; waters in every context including sanitation, plastics, etc. However the form of address is as much in terms of personal transformation as it is in terms of engagement and remediation. ecoart practices are often characterised by eco-centricity as much as any artform distinction. My intention is to explore what this means, and the implications for thinking about public space, particularly in relation to Biesta's formulation of an art that teaches a different way of being in the world.

The conceptualisation of ecoart is formed in part in the practice of artists (some noted above), but also in a series of exhibitions which set out to frame the field. Fragile Ecologies: Contemporary Artists' Interpretations and Solutions, curated by Barbara Matilsky for the Queens Museum in New York in 1992, is often cited as the first. This exhibition focused on the remediation and restoration aspect of the practices, and many subsequent exhibitions adopted this frame. Recently, with ecofeminism(s) at the Thomas Erben Gallery, the ritual and performative strands of early ecoart practices have been revisited. Curator Monica Fabijanska draws out key themes in her associated essay, noting,

...feminist artists still address the degradation of the environment by creating diverse responses to patriarchal power structure, capitalism, and the notion of progress. They invoke indigenous traditions in maintaining connection to nature and intensified [sic] the critique of colonialist politics of overextraction, water privatization, and the destruction of native peoples. They continue to employ social practice and activism, ... Whether

\footnotetext{
${ }^{4}$ Thanks to my colleague Prof. Emeritus Anne Douglas for drawing this point out.

${ }^{5}$ This paper focuses on practices which might broadly be understood to emerge from the visual arts tradition. There is another parallel and interconnected process of emergence in the performing arts.
} 
The Hope of Something Different: Eco-centricity in Art and Education

the earliest or the newest, ecofeminist projects are often collaborations with local communities and scientists. (Fabijanska, 2020, p. 3)

\section{Collaboration, participation, interdisciplinarity}

If ecoart emerges both from practical restorative action and also recognition of multiple forms of agency, there are commonalities between an ecological orientation and social and community practices. Works often operates in both realms, sometimes seamlessly.

Both are interested in different forms of relationality, particularly in sharing and negotiating authorship with communities and creating stories that serve interests beyond their own.

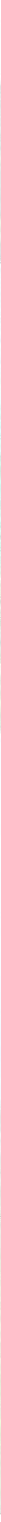

Fig I: Students building the island structures, volunteers helping with planting (Jackie Brookner)

(Photo courtesy of the artist) 
The words 'collaboration' and 'participation' occur regularly in the statements of both social/community and environmental/ecological artists, as highlighted by Fabijanska. The obituary of eminent ecoartist Jackie Brookner serves to highlight this multi-dimensional collaboration and participation,

Among her recent major projects were Veden Taika (The Magic of Water), consisting of three man-made floating islands in Salo, Finland. Veden Taika was a collaboration with local volunteers, regional science experts, the students and faculty of the Salo Polytechnic Institute, the Salo Parks Department and Office of Environmental Protection, Biomatrix Water and the coordination of Finnish artist Tuula Nikulainen. (Malen and Schor, 2015, n.p.)

This short statement highlighting characteristics of Jackie's Veden Taika (2007-20 I0) highlights first working with local volunteers, second with scientists, third learners and then public and private institutions. Last but not least, it acknowledges the Finnish coordinating artist with whom Jackie, as a US based artist working in Finland, collaborated. It is very typical of social and ecological arts practices.

Although the works I'm discussing are public, Brookner's practice was studio-based, concerned with sculptural issues focused by the body. ${ }^{6}$ Amy Lipton describes her underlying interests as, “...porousness and eradicating boundaries - between each other and between all living things, including the planet." She goes on to say, "Her strength was an ability to bring social, environmental and scientific concepts into physical form while maintaining her strong training in formal sculptural principles." (Lipton, 2017, n.p.)

Another of Brookner's public projects is Urban Rain for Roosevelt Community Center, San Jose, CA. The brief was to detain and filter runoff from the roof, particularly stormwater. Patricia Phillips teases out a different set of relationships, this time in terms of landscape,

Brookner's project "Urban Rain" (2008) strikingly connects the new building to its immediate site, as well as a largely invisible watershed. The artist uses stormwater as both a raw material to exploit and a problem to solve producing a fascinating feedback loop of aesthetic decisions and ecological imperatives.

(Brookner, 2009, p. 58)

Phillips defines the project in terms of material (stormwater), but she also draws attention to one of the underlying characteristic of ecoart, the bringing together of aesthetic and ecological aspects. The "feedback loop" of aesthetics and ecology appears to be about problem-solving, but actually reconnects those who experience the work with the world around them.

Brookner's Urban Rain project has a practical problem-solving dimension to it, in that it is part of the stormwater management system. However the work cannot be reduced to that. Urban Rain does not merely aestheticise the stormwater treatment, but opens up questions of ecological value and meaning.

...the original goal was to showcase stormwater treatment measures. What emerged was a design that featured stormwater treatment as truly integrated into the design, both form and function, for the building. The design swiftly exceeds all expectations as it conveys through art work literally and figuratively the not often seen story of how

\footnotetext{
${ }^{6}$ See http://jackiebrookner.com/ for documentation of the artists' career and work.
} 
rainwater connects us all to our creeks, rivers and oceans. (Brookner, 2009, p. 7)

The aesthetic experience constructed as part of the Community Center gives stormwater positive significance within the human environment. Users of the building have their attention drawn to water through the artworks in a way that is intended to shift perceptions, to make a downpour into an aesthetic event in the context of community life. The work expands the building to its catchment and demonstrates, at least in relation to stormwater, how a building can return clean water to the environment, rather than add pollution.

This opens up another key dimension of ecoart practice - the working with "regional science experts". ecoart's hybridity, and an aspect that brings it into proximity with SciArt ${ }^{7}$, is the consistency with which we see ecoartists drawing on and developing expertise in other fields. We might almost take the development of deep expertise in one or more aspects of ecological science; and/or environmental management; and/or specific practices (such as bee-keeping) as another key characteristic of ecoart. In relation to the ecological sciences, we only need look to the Harrisons autobiographical career survey where they name check more than 30 scientists with whom they have worked (Harrison and Harrison, 2016). ${ }^{8}$ Other artists have multiple qualifications at tertiary level, including in ecological sciences (cf Brandon Ballengée and Kerry Morrison).

Writing on this subject is rife with language of multi, cross-, inter-, trans-, a- and postdisciplinarity (Saratsi, 2019). All of these formations attempt to nuance an understanding of different configurations of academic expertise working together to understand and operate in the world. The 'disciplinary' aspect of this language is sometimes the most problematic when we recognise, from the 'deep ecology' perspective, that every living thing knows stuff and uses that knowledge to seek its own well-being. If some dimensions of social and community practice are rights-oriented (Matarasso, 2019, p. 45-46), this is true for some ecoart practices too. One of the most fundamental rights is to have your understanding of the world recognised and valued. Where Sciart is driven by experimentation at the interface of arts and sciences, ecoart perhaps focuses on the need for different forms of knowledge in order to understand the world. Murdo Macdonald argues that every discipline has blind spots (Macdonald, no date). Basarab Nicolescu argues that knowledge is related to different levels of reality (Nicolescu, 1997). This understanding of 'knowing', and of the right to be recognised as 'knowing' is fundamental to the eco-centric perspective. We'll come back to the difference between knowing and understanding in our discussion of Biesta's theory.

These various aspects of participation, collaboration and interdisciplinarity address the first part of Biesta's provocation, "....in the world...", but also have the potential to address the second aspect, "... without occupying the centre of the world." (Biesta, 2017, p. 3).

\footnotetext{
${ }^{7}$ SciArt is another neologism usually defined in terms of collaborations between artists and scientists.

${ }^{8}$ For a wider discussion of the Harrisons work with science and policy see Fremantle, Douglas and Pritchard 2020a and 2020b.
} 


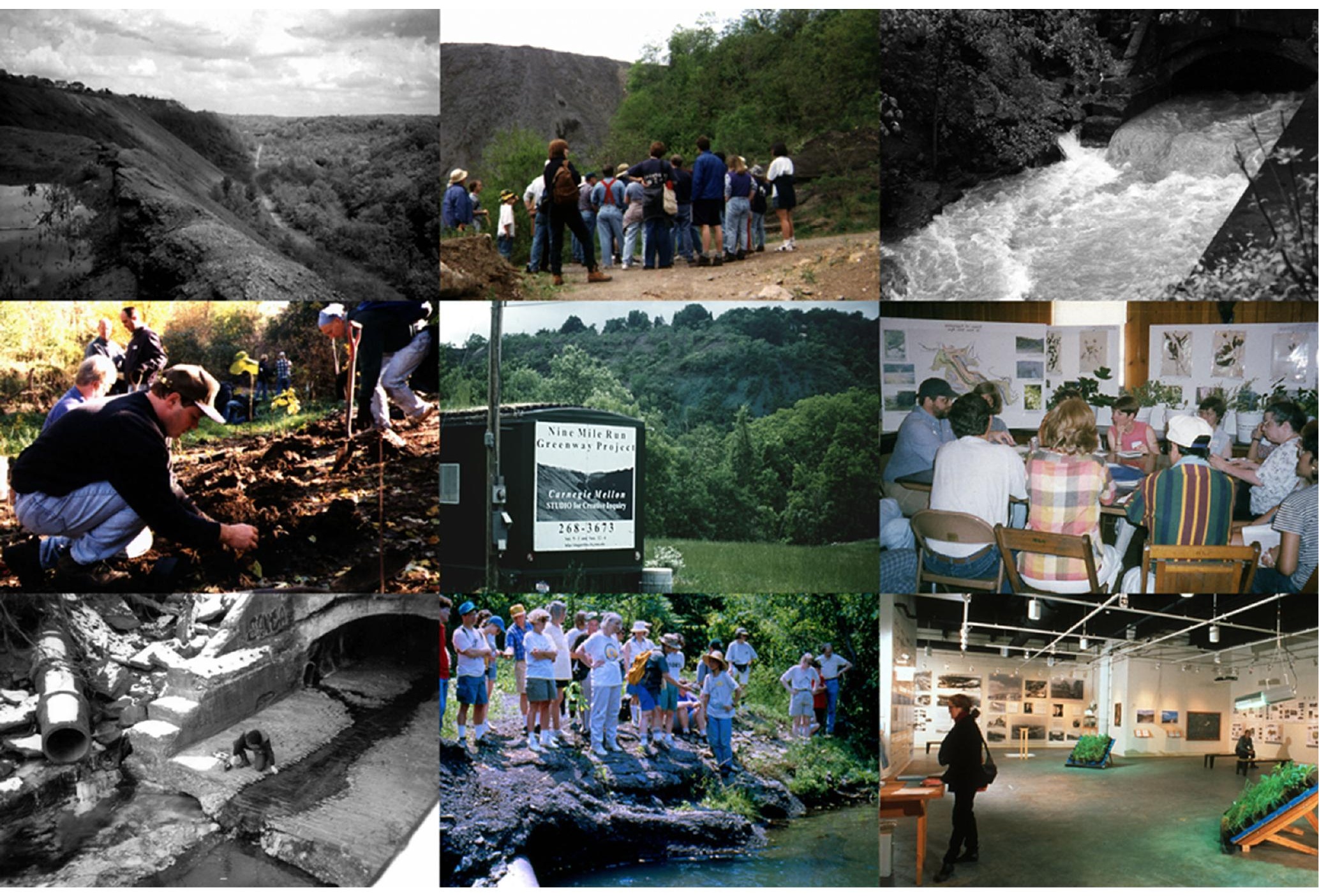

Fig 2: Bingham, Collins, Goto and Stephen. 'Nine Mile Run: Community Dialogues', 1997-2000 (Photo courtesy of the artists)

Tim Collins, writing about four years of team work (1996-2000) on Nine Mile Run Greenway, a major brownfield site in Pittsburgh, Pennsylvania, highlights the role of the work in relation to citizens of the area,

The project team intent was to transcend the role of primary authorship, instead initiating a citizen discourse, and a creative engagement in the definition, form and function of post-industrial public space. (Collins, 200I, p. 25I)

And goes on to say,

The dialogue was intended to complicate the discourse of development, and create a space which would nurture creative citizen voices. (200I, p. 26I)

Collins and partner Reiko Goto-Collins along with other key collaborators developed Nine Mile Run Greenway as a creative-discursive enquiry focused by opportunities to think differently rather than fix problems, attending to shaping the discourse as much as 
restoring the ecology. The Nine Mile Run watershed in Pittsburgh was at once identified as a potential city park by Frederick Law Olmsted, but was actually used by the steel industry resulting in a slag heap 20 stories high. (Curating Cities, No date). ${ }^{9}$

It is critical that the purpose that the team set itself was initiating a discourse, and that they sought to complicate the conventional processes of urban development. As with Brookner, the 'material' focus, in this case slag heaps, is conventionally seen as a 'problem', but the artists open up questions of meaning and value. ${ }^{10}$

Theorists such as Grant Kester, Nicolas Bourriaud, Claire Bishop and Shannon Jackson have written about practices focusing on dialogue, collaboration and the politics of social and community practices. They have, in various ways, helped us to see that an aesthetics of process is the essential focus of artists working with diverse inhabitants and communities. But this isn't an 'aesthetics of facilitation', about 'performing' workshops. Rather it is a deeper interrogation of who has voice, authorship and agency." Grant Kester argues that this is a 'paradigm shift', saying,

I do think there is a paradigm shift occurring, specifically in the way in which we understand aesthetic autonomy. This isn't simply a shift in the content of work, but in the underlying formal organization of artistic production. [...] These changes aren't occurring simply because artists are asking different questions about their own creative practice. Rather, they reflect a broader, trans-disciplinary interest in collective knowledge production. (Kester, 2013, n.p.)

On the one hand this can be understood simply as an aspect of the 'knowledge economy', but Sacha Kagan, one of the key theorists of ecoart, draws attention to the importance of the concept of 'commons'. Commons have become critical, on the one hand underpinning of collective knowledge production (e.g. Creative Commons licensing), and on the other an important counter to the increasing privatisation of public space. If the privatisation of space and information is in order to exploit them, then commons require a different pattern of behaviour, one that requires negotiation and care in order to enable productivity for the benefit of all.

The Harrisons offer another understanding of commons, particularly manifest in Newton Harrison's recent work On the Deep Wealth of this Nation, Scotland (2018), arguing that water, air, soil and forests need to be understood as commons because they underpin all life. To these material commons they add a 'commons of mind', a shared understanding of the value of the things that underpin life (Newton Harrison, 2018). This suggests that attention to the health of these commons, at this point conceiving of putting back more than we take out, will be repaid with abundance. Of course commons has another basic sense in this context which is to resist instrumentalization (WTM Study Group, 2017). In this formation commons is a verb, an activity of understanding how to move towards commons, to turn education and work into commons. This institutes a different regime of value, counter to the economic. After all the most problematic form of 'usefulness' is the usefulness to reducing costs, delivering more exploitable productivity and profit. Commons are a different form of value and meaning, emphatically shared and requiring care.

\footnotetext{
${ }^{9}$ See http://www.collinsandgoto.com for full documentation of projects and publications.

${ }^{10}$ The Artist Placement Group rubric, 'Context is half the work' is a key underpinning to these approaches and ways of working.

II The wider issue of whether participation means democracy is discussed in Harris and Fremantle 20I3.
} 


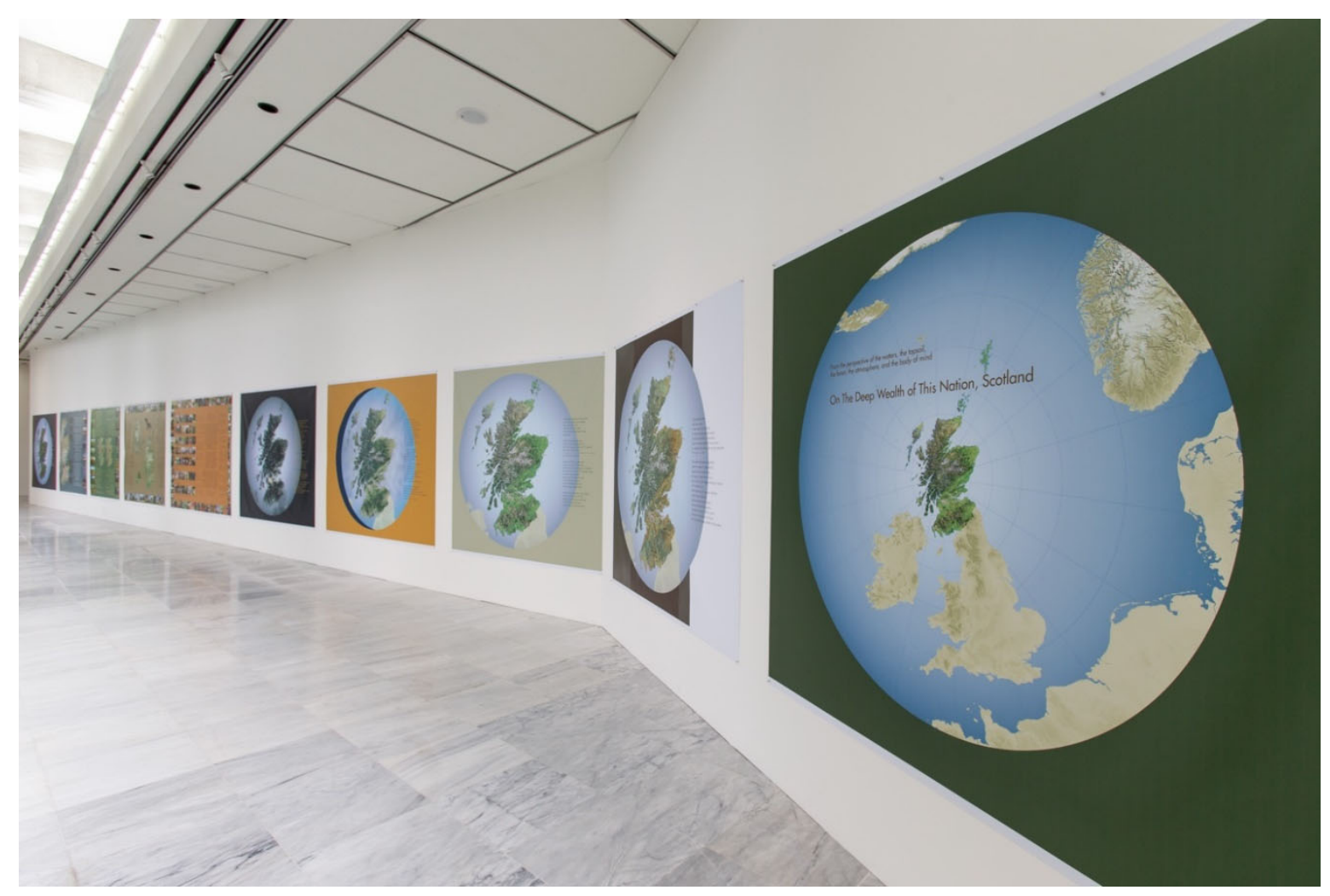

Fig 3: Newton Harrison, 'On The Deep Wealth of this Nation, Scotland', Taipei Biennial (2019) (Image courtesy of the artist/Center for the Study of the Force Majeure and the Taipei Biennial)

Kagan highlights the way the Harrisons take the ecosystem in the places they work to be their client (Kagan, 2014, n.p.). ${ }^{12}$ It is interesting to note that the Harrisons also don't sign their work allowing anyone to take up the ideas and work with them. The lack of a signature means that copyrighting and moral rights are not invoked. The Harrisons aren't afraid of their works being useful, in fact in this way they actively create the conditions for use. This is closely linked to the Harrisons' concept of 'conversational drift', their framing of the way that ideas can take on a life of their own within the wider story of a place. The Harrisons speak of places being the story of their own becoming, with all living and non-living things contributing to the process (Harrison and Harrison, 2004). ${ }^{13}$

More recently Collins, along with others, have developed a specific articulation of the value of arts-led discourse in relation to environmental decision-making (Edwards, 2016). Decision-making and how it is imagined is key to any form of being ".... in the world without occupying the centre of the world". The authors argue that the role of artists in this framing is significant because, "By changing meanings and relationships, an arts-led approach has the potential to change structures and procedures, challenging extant patterns of decision-making." (Edwards, 2016, p. 326). This is significant in terms

12 The Harrisons tell the arts organisations they work with that their role is to act as proxies on behalf of the local ecosystem, the Harrisons' 'real' 'client'. This is of course another flipping of a legal construction, not fundamentally dissimilar to the reinterpretation of the Force Majeure noted above.

${ }^{13}$ For further analysis of the Harrisons' poetics, in particular on improvisation, see Douglas and Fremantle $2016 \mathrm{a}$ and $2016 \mathrm{~b}$. 
of the forms of leadership artists can offer, often providing a distinctive frame for understanding, rather than specific policy or reproducible practice.

One complexity of ecoart is shared agency, sometimes shared authorship, even the rejection of ownership. The main examples l've drawn on thus far have been concerned with stormwater and brownfield, but ecoart has a much wider range of modalities. In a discussion of the recent development of art projects in relation to climate change (not explicitly ecoart) the authors of 'Raising the Temperature' enumerate 12 different 'things' that art can 'do' including, for example, "science communication", "embracing social-ecological complexity", and "shifting awareness and openness to more-thanhuman worlds" (Galafassi et al, 2017, p. 74). Actual projects often straddle several of the categories enumerated. However, the focus on climate change means that the swathe of work associated with remediation and restoration isn't fully represented. However, the question of usefulness is once again foregrounded.

Kagan's essay 'The Practice of Ecological Art' draws attention to other articulations, including that of Suzi Gablik who highlights the connective, reconstructive and ethical at the heart of these practices. In relation to the 'reconstructive' aspect Kagan emphasises the point that ecoart refuses the binary of useless/useful. It's worth bearing in mind that while the Anglo-American art world believes the 'axis of negotiation' is between the intrinsic and the instrumental ('art for art's sake' versus 'art that is useful'), those involved in co-production in the social realm understand the axis to be between the instrumental and the political (cf Turnhout, 2020). We might understand this in terms of, 'Is co-production useful to deliver services?' or 'Is it empowering users and communities to determine what services are useful?' In either case the process is relational, just as art is relational. However, in the latter the relationship is one where value and agency is opened up. Collins explicitly articulated this as the focus of the Nine Mile Run Greenway project saying the aim of the project was to transcend the role of primary authorship.

I have explored aspects of participation, collaboration and interdisciplinarity, and touched on aspects of ecological orientation. I've highlighted the multiple understandings of commons being used to challenge our understanding of public space. I've also offered a different axis on which to think about usefulness. I will now turn to eco-centricity.

\section{Ecoart and 'deep ecology'}

Andrew Patrizio, in his exploration of what an ecocritical art history might be, finds artist Ann Rosenthal's list of values to be "...extraordinarily helpful and comprehensive in articulating the kind of emergent properties we seek in art history..." (Patrizio, 2019, p. 46). He goes on to quote them in full,

I. Land Ethic - recognizing that we are members of an interdependent 'community' that includes not only humans, but 'soils, waters, plants and animals, or collectively: the land' (Leopold).

2. Systems Thinking - visualizing patterns and relationships across disparate information and knowledge systems; applying lessons of ecosystems to our human communities (Capra). 
3. Sustainability - designing our lives, work, products, social systems, and relationships to meet the needs of the present without compromising the ability of future generations to meet their own needs (World Commission on Environment and Development)

4. Social and Biological Diversity - understanding that diversity among disciplines, cultures and species is a prerequisite for systems health and resilience.

5. Social and Environmental Justice - insisting that all species have a right to a clean environment that supports our health and the integrity of the ecological systems that sustain life.

6. Collaboration - bridging the boundaries between disciplines, communities, cultures, classes, genders, and species, respecting what each contributes to designing solutions that work for everyone.

7. Integrity - closing the gap between what we value and how we act in the world. (Patrizio, 2019, pp. 46-47)

Patrizio notes the influence of the 'deep ecology' movement manifest in the references to Aldo Leopold and Fritjof Capra. In this respect Rosenthal's 'eco-centric' orientation is characteristic of ecoart practices, these authors being frequently cited. Broadly speaking the assumption that all living things (if not all things) have intrinsic value, and do not merely exist for human use, is a central tenet of ecoart. In Brookner's Urban Rain stormwater becomes a thing in itself, rather than simply something to be managed by a building's drainage system.

David Haley, another self-defined ecoartist, draws his definition for art from some of the earliest human writing, the Rig Veda. "Rta" is an Indo-Aryan noun/adjective meaning the dynamic process by which the whole cosmos continues to be created, virtuously (Haley, 20I6). Haley understands art, in the widest sense of creativity rather than the narrow sense of the Western tradition, to be part of the ongoing dynamic process of development at an ecological as well as cultural level. For him true art is part of the world making itself, not merely a human product, a way that humanity can participate in the inherent creativity of the universe.

However the focus on the intrinsic value of ecological systems raises its own challenges. Art has traditionally focused on 'the human', and the prioritisation of the ecological does not immediately translate easily into subject matter. This is well summed up by Wallace Heim in her introductory essay to Landing Stages, when she says,

The complexities of human relations with environments and with the climate means overturning the historical weight of the imperturbable, tacit habit that the human subject and its actions amongst other humans are theatre's sole interest. Other suppositions also showed their operation: that the environment or ecology was too materially 'real' for theatre, confounding the usual, more comforting combinations of reality and fiction; and that the conflicts and conditions were too stark to be shown on stage except as represented by activism or science. (Heim, 20I4, p. 6)

I have already explored how ecoart practices go beyond representing science towards forms of integration. In terms of activism, the other adjacency highlighted by Heim, ecoart increasingly frequently engages with and in activism, just as those adopting an eco-centric position can also sometimes be activists. Joanna Macy's three dimensions of 
the great turning: 'holding actions', 'Gaian structures' and 'shift in consciousness' is a very useful way of conceptualising a set of linked modalities in which activism forms a dimension but is not the whole. ${ }^{14}$

The values articulated by Rosenthal and the challenges summed up by Heim frame the need for thinking differently about practices, rather than just incorporating ecology as a subject into conventional art forms. This double challenge, of our relationship with the world, as articulated by Rosenthal, and to the form of the arts as articulated by Heim, requires a transformation.

This challenge is also articulated in The Great Derangement (Ghosh 2016) which explores the capability of the arts, and literature in particular, to address the scale and multidimensionality of the climate crisis, saying,

"When future generations look back upon the Great Derangement, they will certainly blame the leaders and politicians of this time for their failure to address the climate crisis. But they may well hold artists and writers to be equally culpable - for the imagining of possibilities is not, after all, the job of politicians and bureaucrats."

(Ghosh 2016, 135).

This looked for transformation is emergent in the practices of ecological arts including the recognition of agency by all (including more-than-human); and the need to understand how the world works in many dimensions (which has led to these practices being described as hybrid or interdisciplinary).

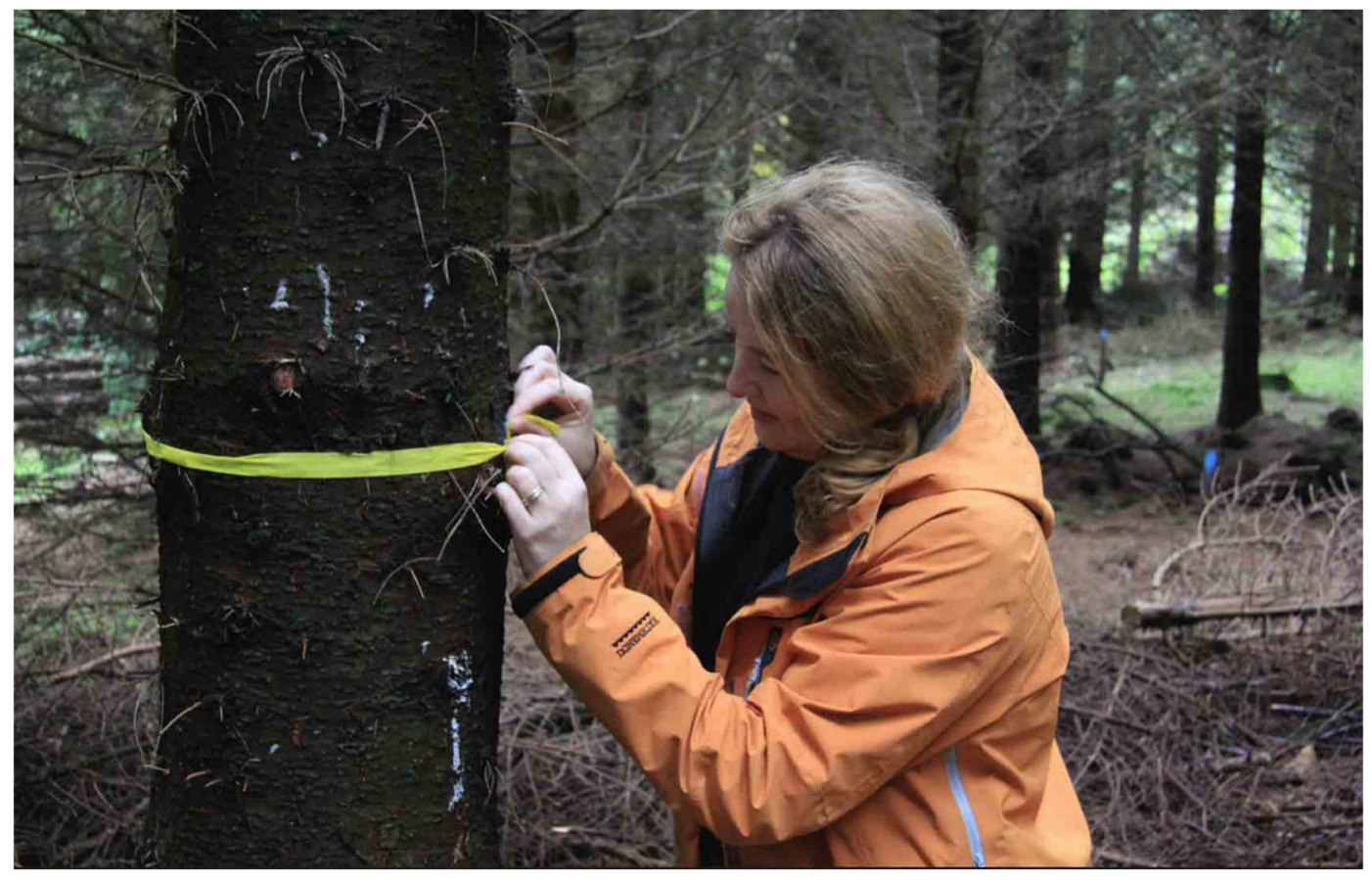

Fig 3: Ecosocial artist Cathy Fitzgerald marking a conifer tree to alert foresters to retain it as a permanent tree for continuous cover forestry management.

Photograph by Martin Lyttle 2015, courtesy of Cathy Fitzgerald

\footnotetext{
${ }^{14}$ See https://workthatreconnects.org/spiral/the-great-turning/ for a fuller description.
} 
Kagan, whilst recognising the reasons for an eco-centric orientation, suggest that those practices which erase the human in their eco-centrism fail to recognise the value of autopoïesis (Kagan, 20 I4, n.p.). Autopoïesis, the self-creation in the development of all lifeforms, is a critical concept which can be traced back to ecological science (cf Maturana and Varella specifically and Lynn Margulis more generally). Elsewhere Kagan has developed the concept of autoecopoïesis as a way of understanding ecoart (Kagan, 2013). Kagan argues that ecoart is a process of self-making as much as it is a process of world-making (and he references Haley in this).

The configuration of practices that work with this double making of self and world is the subject of Cathy Fitzgerald's practice-led research. Cathy Fitzgerald has since 2008 been working on The Hollywood Forest Story, located in Co Carlow, Eire. She has used the ecosophy of Guattari to provide a theoretical frame for what she describes as her eco-social art practice (Fitzgerald, 2018). On the ground she has been working with communities, experts and with the small monocultural conifer plantation where she lives to co-create a flourishing and permanent, mixed-species forest. ${ }^{15}$ Cathy Fitzgerald's 'slow art' is not turning the forest into art in any sense, but rather using art's generative capacity to imagine the possibility of something becoming different - in this case a monocultural conifer plantation.

We might ask of this art made through participation and collaboration, informed by deep ecology and the agency of the more-than-human, are humans the only living things that appreciate the aesthetic of these works? Jackie Brookner's obituary goes on to say,

Emblematic of her work, the islands provide nesting habitat for birds and plant based filtration for improving water quality in the Salo Bird Pools, lagoons that were formerly used in the sewage treatment processes of the Salo Municipal Sewage Treatment Facility. Because an abundance of migrating and nesting birds now use the lagoons, the pools have been established as a EU-directive conservation site.

(Malen and Schor, 2015, n.p.)

Can we imagine that the migrating species, who obviously know huge areas of landscape, now value this changed part of their landscape? Does the fact that a sewage treatment facility is so much 'healthier' make it a more significant part of their landscape? Is a small forest becoming diverse significant to other living things? Is that a form of beauty? Do they have a 'Right' to this?

Kester has recently suggested that art 'offer[ing] the hope of something different from "the world as it is," is valued above all else,' (Kester, 20I5, n.p.). A concern for relations, the connectedness of things, is not exclusive to the arts. As Kester argues, this change is a wider paradigm shift across many aspects of society.

The distinctive contribution of both community and ecological arts practices is in the sharing of authorship and the recognition of the authorship in others. Ultimately the question is whether the work (the art) can be taken up by inhabitants (or visitors) and used for their own eco-cultural well-being. What would it mean if we had to answer that request?

\footnotetext{
${ }^{15}$ See http://hollywoodforest.com for a full account of this work.
} 


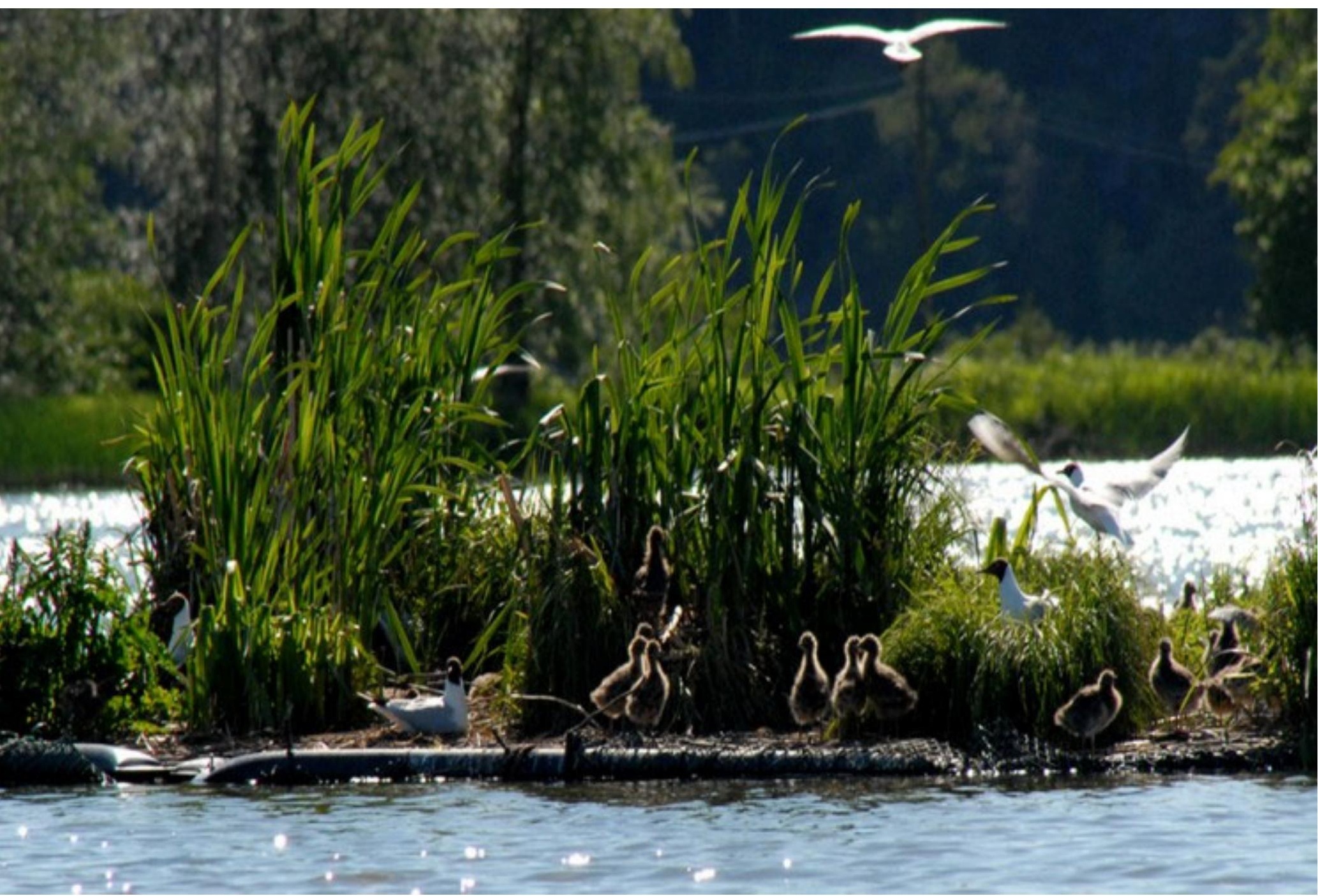

Fig 5: Jackie Brookner, 'Veden Taika', Halikonlahti Bird Pools, Salo, Finland (2007-2010) Close up of Black headed tern chicks, Spring 2012 (with permission of the artist's estate)

I now need to turn to Biesta to understand more clearly how his idea of "... in the world without occupying the centre of the world." (Biesta, 2017, p.3) and in particular the role of art, might have an eco-centric dimension or at least help us understand ecoart.

\section{...in the world without occupying the centre of the world}

Biesta's concern is with education and educational theory, and specifically with the education of the young. However, the primary text drawn on for this essay is Letting Art Teach: Art education 'after' Joseph Beuys (Biesta, 2017) in which Biesta explores how art and education share some challenges. He starts from the assumption that both art and education are suffering from being expected to be useful, and that the usual defence for art, in terms of its capacity to engender expressiveness, is dangerous in itself. The pivot of his argument is the phrase, "....in the world without occupying the centre of the 
world." (Biesta, 2017, p. 3) which he credits to Phillipe Meirieu. It is important to note that Meirieu's use is positioned within the classroom and that Biesta is not developing his argument rooted in deep ecology, though he does address the issue of the limits of the world (Biesta, 2017, p. 58), and he does juxtapose his perspective with an egological one (Biesta, 2017, p. 56). There are many forms of 'centre' that could be brought into question at many levels (artworld, patriarchal, normative) beside that of the anthropocentric and I am interpreting this phrase as indicating a scope which Biesta himself might not envisage.

The book is a juxtaposition of Biesta's text with images from Joseph Beuys' 1965 Action Explaining pictures to a dead hare. Beuys is an apposite foil for Biesta' thesis not least because Beuys conceived of his life as teaching, saying,

To be a teacher is my greatest work of art. The rest is a waste product, a demonstration. (Beuys, 2005, p. 27)

Explaining pictures to a dead hare was a three hour performance at Galerie Alfred Schmela in Düsseldorf. Beuys, head covered in honey and gold leaf, one shoe with a felt sole, the other with an iron sole, carried a dead hare from picture to picture. The audience outside the gallery couldn't hear what Beuys said to the hare, only watch as he touched the hare's paw to pictures, whispered in its ear, and then sat cradling it, continuing with his monologue.

Biesta draws out a number of key aspects in which this particular performance exemplifies a key characteristic of teaching. Biesta focuses on the act of 'showing'. 'Showing' is a fundamentally relational act made up of "someone showing something to someone" (Biesta, 2017, p. 44). This drawing of attention is critical and opens up questions about how we 'get' attention, and in particular of the need for the learner to be open to learning; of how attention needs to be of the head, heart and hands; and how this showing is a double showing, showing the thing and also showing the criteria to understand the significance or value of the thing.

Desire and its relationship with the world has a central role in Biesta's educational theory. He argues that the purpose of education is that, "...the educated person is not a thing or a product, but a human being with an altered outlook." (Biesta, 2017, p. 54). This altered outlook is one in which the individual has encountered the 'resistance of the world', manifest in the practical reality of what happens when we do things: they don't always happen the way we desire. That resistance, e.g. of stone breaking the wrong way, brings us up against our own desires. Speaking of the way education, and in particular the 'interruption' of education is a practice in preparation for life, Biesta says education is also,

...offering resistance so that desires can become visible and can be encountered and the work of selecting, rearranging and transforming one's desires can be taken on...

(Biesta, 2017, p. 90)

Desire and the "selecting, rearranging and transforming" of desires is critical to the project of "...not occupying the centre of the world." Biesta argues that failure to attend to the resistance of the world in relation to our desires has two forms. On the one hand failure is when, "... if we have too little consideration for the integrity of what we encounter, that our intentions and ambitions result in the destruction of what we encounter, the destruction of what offers resistance." (Biesta, 2017, p. 64). Many would argue that the ecological crises are precisely the manifestation of this failure. 
The alternative failure is that, “...the frustration of encountering resistance leads us to withdrawal. ... If the first response runs the risk of destroying the world, the second response runs the risk of destroying ourselves, destroying our very existence in the world, our existence as subject." (Biesta, 2017, p. 64-65). This latter argument is directly related to Kagan's argument against a wholly eco-centric position, losing sight of the human aspect of poesis.

There is a specific role for art, with its particular attention to meaning, value and subjectivity, in relation to desires,

Art can make our desires visible, give them form, and by trying to come into dialogue with what or who offers resistance, we are at the very same time engaged in the exploration of the desireability of our desires and in their rearrangement and transformation. (Biesta, 20I7, p. 72)

Biesta's idea of 'in the world' is drawn from Hannah Arendt's political philosophy, and he specifically draws on her differentiation of knowledge from understanding. Understanding is distinct from knowing, the latter characterised by correct information and scientific forms of knowledge. Rather, understanding is existential, and concerned with the experience of being in the world (Biesta, 2017, p. 98-99). Biesta further develops this, and opens up the second part of the key phrase, the part about not 'occupying the centre' by arguing that understanding goes beyond sense-making, saying of Arendt,

...she pushes understanding towards the existential end of the spectrum, away from sense-making and interpretation, away from acts of cognition, away from the work of the head, and towards the lifelong task of trying to be at home in the world. (Biesta, 2017, p. 99).

Biesta's examples of resistance are physical, but Ernesto Pujol offers a different example of resistance, as well as suggesting a way to respond to resistance that seems to me at least in tune with both Biesta, but also Beuys. Pujol, in his short essay 'Walking Rejections' reflects on the rejection of proposals by curators and funders (Pujol, 2018, p. 124-5). Pujol in particular highlights curators rejecting proposals for walks because they don't fit current preferences and institutional politics. His response to rejection is to pause and to explore stillness. He says,

When someone rejects my walk, I do not cease to walk but I slow down to a pause. I see it as an invitation to pause reflectively. It may not be the invitation I wanted, but it is the one received. Therefore, by slowing my steps and reflecting, I begin to engage in a meditative stillness. (Pujol, 2018, p. 124).

This evocative response to the resistance of the world opens up a way of understanding the how to not destroy ourselves or the world. It is only one way in relation to one resistance, but it does correlate with Biesta's concern for understanding as being more than sense-making, highlighting the "What is this asking of me?" aspect of understanding. It is worth exploring this in relation to our earlier discussion of usefulness. There are aspects of ecoart that can be understood in terms of problem-solving (as was highlighted in relation to Brookner's Urban Rain project). Jeremy Till, writing on architecture and participation, reframes the role of design from 'problem-solving' to 'sense-making' (Till, 2005, p. 36). This is an important shift, not to be underestimated. But in following Arendt and moving beyond understanding as sense-making to 
conceiving of understanding as the world asking of us, Biesta is fundamentally opening up agency to the more-than-human, thus also opening up the possibility that something else is 'occupying the centre'.

This is the interruption that is required by education, as noted above, which means that the learner must be willing to have their attention drawn, be willing to learn in terms of being taught. Hence Biesta argues that this goes beyond "How can I make sense of this?" and "What can I learn from this?" to "What is this trying to teach me?" (Biesta, 2017, p. 100).

\section{Conclusion}

In setting out to explore what a different practice in relation to public space might be and exploring how ecoart practice might be different, l've touched on its affinities with social practice; aspects of collaboration and the importance of the commons; focused on what eco-centricity might mean both in a general sense as well as in a nuanced reading that doesn't lose sight of the human. l've argued that Biesta's phrase "....in the world without occupying the centre of the world." opens up the potential for ecocentric theorisation.

It is important to note that Biesta doesn't fully take on Beuys' approach, including specifically Beuys' concern with the role of intuition as a form of rationality, or his wider concerns with the spiritual aspects. These are often manifest through the symbolic importance of particular animals (including the hare). Biesta also doesn't address the use of the absurd as a form of interruption intended to create space for understanding, so plainly evident in the performance How to explain pictures to a dead hare. ${ }^{16}$ Biesta however is alert to the fact that Beuys' performance is to be perceived, rather than 'made sense of'. It is intended to evoke an understanding without knowing what it 'means' (Biesta, 2017, p.43).

The use of the symbolic is central to Beuys' construction of situations where we are forced to consider "What is this asking of me?", of situations where our desires are thrown into perspective and revealed to us. It is after all in the "selecting, rearranging and transforming" of desires that our relationships with the world as home can be transformed.

Beuys uses symbolism as a means to open up eco-centricity, to give agency to the more-than-human. Other artists use different approaches including particular ways of constructing discourse (Collins and Goto) or through giving voice to the web of life (Harrisons).

The Harrisons' construction of the Force Majeure is particularly salient because in effect it acknowledges that the combination of environmental crises occupy the centre of the world and we can only adapt. The Harrisons, in articulating the current environmental crises as 'the Force Majeure', are precisely framing an understanding of the current moment in terms of What does this understanding of the world ask of me? In the Manifesto the Harrisons argue that personal interest takes precedence in most discourse, that social issues are somewhat attended to and that ecological issues are

\footnotetext{
${ }^{16}$ I'm grateful to my colleague Prof Emeritus Anne Douglas for this important observation. Absurdity is an important aspect of the arts and is precisely used to create interruption for different forms of understanding to become possible, particularly forms of understanding that involve living with the limits of understanding.
} 
less so. In another work, Serpentine Lattice (1993) concerning the Pacific Northwest Temperate Rainforest, they offer this meditation,

THEN

A NEW REVERSAL OF GROUND COMES INTO BEING

WHERE HUMAN ACTIVITY BECOMES A FIGURE

WITHIN AN ECOLOGICAL FIELD

AS SIMULTANEOUSLY THE ECOLOGY CEASES TO BE

AN EVER SHRINKING FIGURE

WITHIN THE FIELD OF HUMAN ACTIVITY ${ }^{17}$

(Harrison \& Harrison 1993, PP 5-6)

\section{References}

Bateson, G. (1979) Mind and Nature: A Necessary Unity. London: Wildwood House.

Beuys, J. (2005). 'Statements by Joseph Beuys'. Cencrastus: Scottish and International - Joseph Beuys in Scotland (80).

Biesta, G. (2017) Letting Art Teach: Art education 'after' Joseph Beuys. Arnhem: ArtEZ Press.

Bishop, C. (2012) Artificial Hells: Participatory Art and the Politics of Spectatorship. London: Verso.

Brookner, J. (2009) Urban Rain: Stormwater as a Resource. City of San Jose/Oro Editions.

Collins, T. (200I) 'Conversations in the Rust Belt' in Herzogenrath, Bernd (ed), Critical Studies, From Virgin Land to Disney World: Nature and Its Discontents in the USA of Yesterday and Today, (26). Pp. 25I-276.

Curating Cities: a database of eco-public art. (no date) Nine Mile Run - STUDIO for Creative Inquiry, Carnegie Mellon University. Pittsburgh, USA, 1996-2000. [online] Available from: http://ecopublicart.org/nine-mile-run/

Fabijanska, M. (2020) ecofeminism(s), Thomas Erben Gallery. Jun-July 2020. [online] Available from: http://www.monikafabijanska.com/s/ecofeminisms-essay-FINAL_FINAL.pdf

Fremantle, C. (2015) 'The hope of something different'. In A restless art: thinking about community and participatory art [online] https://arestlessart.com/20I5/I2/I7/chris-fremantle-the-hope-ofsomething-different/

Douglas, A., and Fremantle, C. (2016a) 'What Poetry Does Best: The Harrisons' Poetics of Being and Acting in the World'. In Helen Mayer Harrison and Newton Harrison. The Time of the Force Majeure: After 45 Years Counterforce is on the Horizon? New York: Prestel. pp. 455-460.

Douglas, A., and Fremantle, C. (2016b) 'Inconsistency and Contradiction: Lessons in Improvisation in the work of Helen Mayer Harrison and Newton Harrison'. In (ed) Brady, J., Elemental: an Arts and Ecology Reader. Manchester: The Gaia Project. PP. I53-I8I.

Fitzgerald, C. (2018) The Ecological Turn: Living Well with Forests To Articulate Eco-Social Art Practices Using a Guattari Ecosophy and Action Research Framework. PhD Thesis, National College of Art and Design, Dublin. Available from: http://ncad.academia.edu/CathyFitzgerald

\footnotetext{
${ }^{17}$ Parts of the work including a video can be seen on the Harrison Studio website http://theharrisonstudio.net/serpentine-lattice
} 
Fremantle, C., Douglas, A., and Pritchard, D. (2020a) 'In The Time Of Art With Policy: The Practice of Helen Mayer Harrison and Newton Harrison Alongside Global Environmental Policy Since the 1970s'. In (eds) Cartiére and Tan. Routledge Companion to Art and the Public Realm. Abingdon: Routledge. pp. 300-3।4.

Fremantle, C., Douglas, A., and Pritchard, D. (2020b) "The Harrisons' Practice in the Context of Global Environmental Policy and Politics from the 1960s to 2019: A Timeline'. In (eds) Cartiére, C., and Tan., L., Routledge Companion to Art and the Public Realm. Abingdon: Routledge. Pp. 315-332.

Ghosh, A. (2016) The Great Derangement: Climate Change and the Unthinkable. Chicago: University of Chicago Press

Haley, D. (2016) 'A question of values: Art, Ecology and the Natural Order of Things' in Brady, J. (ed.) Elemental: an arts ecology reader. Manchester: Gaia Press Project/Cornerhouse pP 4I-62.

Harris, P. and Fremantle, C. (20I3). 'Practising equality? Issues for co-creative and participatory practices addressing social justice and equality'. Participations: journal of audience and reception studies, 10(2), pages 183-200. Available from: http://www.participations.org/Volume\%2010/lssue\%202/I I.pdf

Harrison, H.M., and Harrison, N. (2004) Santa Fe Watershed: Lessons from the Genius of Place, Santa Fe Art Institute. II December 2004-22 January 2005. Santa Fe, NM: Santa Fe Art Institute.

Harrison, H.M., and Harrison, N. (2016) The Time of the Force Majeure: After 45 Years Counterforce is on the Horizon? New York: Prestel.

Harrison, H.M., and Harrison, N. (1993) Serpentine Lattice. Portland Oregon: Reed Institute and Douglas F. Cooley Memorial Art Gallery 2 February-I5 March 1993. Portland, OR: Reed Institute and Douglas F. Cooley Memorial Art Gallery.

Harrison, N. (2018) On the Deep Wealth of this Nation, Scotland. I I-25 September 2018 the Barn, Banchory, Aberdeenshire. Available from: http://www.centerforforcemajeure.org/deepwealth-of-this-nation-scotland

Heim, W., and Margolies, E. (20I4) Landing Stages: Selections from the Ashden Directory of Environment and Performance 2000-2014. London: Crinkle Crankle Press.

Kagan, S. (2013) Art and Sustainability: Connecting Patterns for a Culture of Complexity. 2nd Edition. Bielefeld: Transcript Verlag.

Kagan, S. (2014) "The Practice of Ecological Art", Plastik: Art \& Science, http://art-science.univparis I.fr/plastik/document.php?id=866 
Kester, G. (2013) "On Collaborative Art Practices”, Praktyka Teoretyczna, http://www.praktykateoretyczna.pl/granth-kester-on-collaborative-art-practices/ accessed 7.12. 2015.

Kester, G. (20I5) "Editorial”, Field: A Journal of Socially Engaged Art Criticism, Vol 2. http://fieldjournal.com/issue-2/kester-2. Accessed 7 December 2015

Lipton, A. (2017). Why Matter Matters? Women Eco Artists' Dialog Magazine [online] Available from: https://directory.weadartists.org/jackie-brooker-matter-matters

Macdonald, M. (no date) Art and Science: A Note on Interdisciplinarity. [online] Available from: https://murdomacdonald.wordpress.com/art-and-science-a-note-on-interdisciplinarity/

Malen, L. and Schor, M. (20I5) "In Memoriam: Jackie Brookner", NewsGrist. [online] available from http://www.newsgrist.typepad.com/underbelly/2015/05/in-memoriam-jackie-brookner-19452015.html. Accessed 7 December 2015.

Matarasso, F. (2019) A Restless Art: How participation won, and why it matters. London Calouste Gulbenkian Foundation/Central Books.

Matilsky, B. (1992) Fragile Ecologies: Contemporary Artists' Interpretations and Solutions, Queens Museum of Art, New York. September I5-November 29 1992. New York: Rizzoli.

Nicolescu, B. (1997) The Transdisciplinary Evolution of the University Condition for Sustainable Development. International Congress "Universities' Responsabilities [sic] to Society", International Association of Universities, Chulalongkorn University, Bangkok, Thailand, November 12-14. [online] Available from: http://ciret-transdisciplinarity.org/bulletin/b /2c8.php

Patrizio, A. (2019) The Ecological Eye: Assembling an Ecocritical Art History. Manchester University Press.

Saratsi, E., Acott, T., Allinson, E., Edwards, D., Fremantle, C., and Fish, R. (2019) Valuing arts and arts research. Valuing nature paper, 22. UK: Valuing Nature [online]. Available from: https://valuing-nature.net/valuing-arts-and-arts-research

Till, J. (2005) 'The Negotiation of Hope'. In (eds) Jones, P.B., Petrescu, D., and Till, J., Architecture and Participation. London and New York: Taylor \& Francis. Pp 23-4I.

Turnhout, E., Metze, T., Wyborn, C., Klenk, N., and Louder, E. (2020) 'The politics of coproduction: participation, power, and transformation', Current Opinion in Environmental Sustainability. Vol 42. https://doi.org/10.1016/j.cosust.2019.11.009

WTM Study Group (2017) Drawn in Drawn Out, Studying the Commons. Utrecht: Casco: Office for Art, Design and Theory. 